\title{
Monks, Manuscripts, Muhammad, and Digital Editions of the New Testament
}

Reaching back to the mythic world of the Library of Alexandria, editors have honed the skills associated with creating editions of texts preserved in various documentary sources, focusing largely on works of literature that are of value to bookish circles (both ancient and modern) and central to the production of culture. These include the Bible (which has become one of the most contentiously edited traditions since the advent of print), the literature of classical antiquity, and other important vernacular works like Shakespeare, the Song of Roland, and Dante's Inferno among many others. ${ }^{1}$ Critical editions represent and weigh the variety of documents that comprise culturally or academically interesting works of literary art; they are powerful cultural machines that negotiate and condense individualities of the documentary sources of a literary tradition into a textual narrative. ${ }^{2}$ As such they remain central to the humanities and biblical studies in particular, forcefully shaping forms of scholarly engagement.

The modern editorial process, however, has been fine-tuned in the context of print culture, which is potentially problematic when the object of study is nontypographic. The reliance on print technologies also leads to a necessary selectivity in the presentation of material, a selectivity constrained both by the pragmatics of presentation, and also by editorial choice, curating the breadth of the tradition in an effort to transmit only its salient features. Editions shape perceptions of the works they represent, but they are not immune to the social and technological pressures of the context of their own making. Their representations are shaped by the economics of bookspace and the history of editorial praxis, forces that create a necessary abstraction that distils the relevant portions of a documentary tradition that serves a foundation higher order interpretive activities.

1 For an overview of textual scholarship from antiquity, cf. David Greetham, "A History of Textual Scholarship," in The Cambridge Companion to Textual Scholarship, ed. N. Fraistat and J. Flanders (Cambridge: Cambridge University Press, 2013): 17-41. On trends in vernacular editing see Bernard Cerquiglini, In Praise of the Variant: A Critical History of Philology, trans. B. Wing (Baltimore: The Johns Hopkins University Press, 1999), esp. 72-82 for his prescient anticipation of the digital edition.

2 Cf. Jerome McGann, Radiant Textuality: Literature after the World Wide Web (New York: Palgrave Macmillan, 2001), 53-97 for an articulation of the prowess and restrictions of the classic critical edition and editorial theory and McGann, A New Republic of Letters: Memory and Scholarship in the Age of Digital Reproduction (London: Harvard University Press, 2014).

Ә Open Access. (C) 2020 Garrick V. Allen, published by De Gruyter. () BY-NC-ND This work is licensed under a Creative Commons Attribution-NonCommercial-NoDerivatives 4.0 International License.

https://doi.org/10.1515/9783110634440-009 
When we edit, we create for ourselves pictures of great detail, but not comprehensive representations; key parts of the traditions that we edit become inaccessible in the process.

A notable consequence of editorial practice is that modern print editions of the New Testament, even the new editio critica maior (ECM), fundamentally divorce texts from the manuscript artefacts that transmit them, creating a situation in which the works of the New Testament are further abstracted from their material contexts. ${ }^{3}$ Practically, this means that essential characteristics of non-typographic traditions like segmenting, format, paratexts, marginalia, corrections, diachronic production layers, commentaries and catenae are rarely represented in critical editions in ways that do justice to their diversity and expressive value. These items and others comprise an artefact's bibliographic code, features that fundamentally influence the processes of reading and cognition. Most critical editions of the New Testament are purely textual abstractions.

But what happens when the medium and functionalities of the critical edition change? The ECM projects, of which the fascicles of Acts and the Catholic Epistles have appeared, ${ }^{4}$ have also facilitated the development of digital editions. For example, a digital edition of Acts was recently launched that reconnects text to manuscripts by providing hyperlinks in the apparatus to corresponding images, transcriptions, and metadata, although the platform is currently designed only for research experimentation and is not yet fully vetted or developed in terms of data or interface. ${ }^{5}$ The ongoing production of the ECM offers a distinctive opportunity to theorise the future of the critical edition of the New Testament since its digital form is still in production and because the fascicle for the book of Revelation will be a "born digital" edition. The media of critical editions is in a state of flux.

In response to these impending fundamental changes to editions of the New Testament this discussion argues that digital editions open unexpected critical avenues when they integrate a critically constructed text with the material

3 This principle is codified in the text-genetic method used in evaluating variation units for the ECM editions called the Coherence-Based Genealogical Method. Cf. Gerd Mink, "Contamination, Coherence, and Coincidence in Textual Transmission," in The Textual History of the Greek New Testament: Changing Views in Contemporary Research, ed. K. Wachtel and M.W. Holmes (Atlanta: Society of Biblical Literature, 2011): 141-216 (here 146). On the CBGM, cf. Tommy Wasserman and Peter J. Gurry, A New Approach to Textual Criticism: An Introduction to the Coherence-Based Genealogical Method (Atlanta: Society of Biblical Literature, 2017).

4 B. Aland et al., eds., Novum Testamentum Graecum Editio Critica Maior IV. Die Katholischen Briefe, 2nd ed. (Stuttgart: DBG, 2011); H. Strutwolf et al., eds., Novum Testamentum Graecum Editio Critica Maior III. Die Apostelgeschichte (Stuttgart: DBG, 2017).

5 Available at http://ntvmr.uni-muenster.de/nt-transcripts. 
artefacts. To illustrate this point in a concise way, I explore the expressive features of the manuscripts of Revelation that comment on the number of the beast and its significance ( $\operatorname{Rev} 13: 18)$, one of the most exegetically contentious texts in the Apocalypse and a text of considerable interest in the history of interpretation. Forty-eight of Revelation's 310 Greek manuscripts ${ }^{6}$ contain marginal notes in connection to Rev 13:18 that decode the wordplay embedded in the text, usually drawing from traditional sources like Irenaeus, Hippolytus, Oecumenius, or Andrew of Caesarea, but also upon entrenched cultural anxieties that manifest as anti-Islamic sentiment in the face of Ottoman hegemony in the medieval and early modern periods (see appendix).

These marginal traditions, always omitted from critical editions, are important because they contextualise the relationship between Revelation's textual history and reception history, providing unanticipated information that informs discussions on monastic textual cultures, channels of transmission of ancient interpretive traditions, and the eschatological politics of religious tension and cultural subservience. Digital editions provide the opportunity for researchers to reconnect the expressive and paratextual features of manuscripts with their textual characteristics, creating editions that are not necessarily organized around the idea of the "original" text of the author ${ }^{7}$ or "initial" text, ${ }^{8}$ but around a more decentralized conception of representing the tradition writ large. Instead of scanning diligently through every image of every manuscript, users of a curated

6 This number does not include commentary manuscripts, marginal notes like those in GA 522 (Oxford, Bodleian, Canon gr. 34), which simply decodes the number abbreviations in 13:18 and 14:11 in Arabic numerals, or now-illegible or tachygraphic marginal notes like those in the margins of catena manuscripts like GA 91916171746 and 2669 that likely also comment on the passage. Other manuscripts, like GA 2046 and 2069, appear to preserve marginal comments, but they simply represent the insertion of Andrew of Caesarea kephalaia titles by a later hand, while 2031 simply repeats that "the number of the beast is $\chi \xi \varsigma$.” For a recent overview of Revelation's manuscript tradition, cf. Markus Lembke, "Beobachtungen zu den Handschriften der Apokalypse des Johannes," in Die Johannesoffenbarung: Ihr Text und ihre Auslegung, ed. M. Labahn and M. Karrer (Leipzig: Evangelische Verlagsanstalt, 2012): 19-69.

7 Cf. D.C. Parker, Textual Scholarship and the Making of the New Testament (Oxford: Oxford University Press, 2012), 26-29 for a critical evaluation of this approach, which he calls the "authorial fallacy." So also Kathryn Sutherland, "Anglo-American Editorial Theory," in The Cambridge Companion to Textual Scholarship, ed. N. Fraistat and J. Flanders (Cambridge: Cambridge University Press, 2013): 57-58; Ronald Hendel, Steps to a New Edition of the Hebrew Bible (Atlanta: Society of Biblical Literature, 2016), 271-95.

8 Holger Strutwolf, “Original Text and Textual History," in The Textual History of the Greek New Testament: Changing Views in Contemporary Research, ed. K. Wachtel and M.W. Holmes (Atlanta: Society of Biblical Literature, 2011): 23-41. Cf. more generally E.J. Epp, "The Multivalence of the Term ‘Original' Text in New Testament Textual Criticism,” HTR 92 (1999): 245-81. 
digital edition will be able to access the data through a single hyperlink and perceive the innate interrelationships between text and artefact, form and content. This conception of the critical edition views biblical manuscripts as embodied textual objects where the relationship between form and content is inextricable. If the move from print to digital formats is indeed as significant as the shift to print from manuscripts or from roll to codex, ${ }^{9}$ then we are only beginning to imagine what the editions of the future can do.

In essence, the following discussion explores the consequences of editing in an age where "original" texts are no longer the express aim of editorial praxis, where editions are no longer proscribed by the modalities of print, and where scholarly attention is returning a philological sensibility that recognised in inherent material value of every witness of a given tradition. Digital editions offer unique pathways to information not prioritised by classic print editions, information that enhances the analysis of the work from both historical-critical and reception-historical perspectives. Analysing Rev 13:18 illustrates the connectivity between text, manuscript, and editions, underscoring the complexity of the New Testament as a diverse aggregate. ${ }^{10}$ The questions raised in this analysis are particularly pressing in an era where biblical scholars continue to negotiate the dual imperatives of print and digital culture, an ongoing negotiation that has led to a renewed examination of the ways that media influences message and the ways bibliographic and non-typographic forms are expressive parts of the tradition.

Throughout this discussion we should keep in mind, however, that digital editions are not prima facie better or more complex than classic print editions. Digital and print are complimentary mediums structured by a desire to retain our cultural inheritances, and critical editions are among the most complex and powerful progeny of print culture. ${ }^{11}$ This examination is about theorizing how digital editions can provide both the textual acumen of classic editions and necessary access to digital and edited forms of the documents that stand behind these editions. As Jerome McGann has eloquently argued,

digitizing the archive is not about replacing it. It's about making it usable for the present and the future. To do that we have to understand, as best we can, how it functioned - how it made meanings - in the past. A major task lying before us - its technical difficulties are

9 Greetham, "History," 39.

10 Cf. Neil Fraistat and Julia Flanders, "Introduction to Textual Scholarship in the Age of Media Consciousness," in The Cambridge Companion to Textual Scholarship, ed. N. Fraistat and J. Flanders (Cambridge: Cambridge University Press, 2013): 1-15 which emphasises the interrelatedness of material culture and textual scholarship, a relationship that is becoming more tangible in the digital age.

11 McGann, Radiant Textuality, 168-72. 
great - is to design a knowledge and information network that integrates, as seamlessly as possible, our paper-based inheritance with the emerging archive of born-digital material. ${ }^{12}$

Before the editorial and technical work on a comprehensive set of digital editions of the New Testament is complete - and I think that this is the task of the next generation of editors - I want to imagine one possible nexus of scholarship that the edition of the future will stimulate: the dynamic relationship between reception history and the materiality of manuscripts. ${ }^{13}$ We are currently situated in a time of convergence between two great cultural mechanisms of print and digital culture that the following examples help us negotiate.

\section{The Number of the Beast in Text, Tradition, and Nestle-Aland ${ }^{28}$}

Before approaching the manuscripts, we need to see the larger narrative of which Rev 13:18 is an integral part and better understand how the Nestle-Aland editions have influenced this text's interpretation. Revelation 13 introduces us to the sea beast who has "ten horns and seven heads, and on his horns are ten crowns and on his heads are blasphemous names," "appearing like a leopard and his feet like a bear and his mouth like the mouth of lion" (13:1-2). The beast is given authority and a throne by the red dragon whose assault on the heavenly woman and her offspring in chapter 12 fails, pursuing her until the earth comes to her aid by swallowing up the water that the dragon disgorges. The vision is all the more marvellous since one of the beast's heads has been healed of a mortal wound (a direct comparison to the slain-but-standing lamb in 5:6-8); the whole world marvels at and worships the beast, who blasphemes with his mouth, and takes authority for forty-two months over every tribe, tongue, and nation (13:3-8). The author then steps out of the vision report, offering a word of patient endurance for the saints (13:10).

As if this beast was not menacing enough, a beast arises out of the earth in 13:11 with a similar profile: it has two horns, is zoomorphic (lamb-like), and speaks like a dragon. It is the inimical equivalent of the lamb who receives worship in the heavenly court in chapter 5 , its serpentine features connecting it to the red dragon from chapter 12. The cosmic topography of Revelation's protagonists

12 McGann, A New Republic of Letters, 22.

13 As an example of this dynamic in biblical studies, cf. Brennan W. Breed, Nomadic Text: A Theory of Biblical Reception History (Bloomington: Indiana University Press, 2014). 
and antagonists is complex and interconnected. The land beast reinforces the worship of the sea beast by performing signs, by making fire fall from heaven (13:12-13). It propagandizes for the sea beast, leading humans astray, compelling them to make cultic idols of the sea beast with the miraculously healed head. The land beast is given authority to give voice to the image of the beast, allowing it to speak. Those who do not worship the sea beast are annihilated, and the land beast forces all to take a mark on their right hand or forehead in order to partake in economic activity. The mark of this beast is "the name of the beast

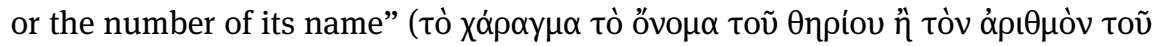

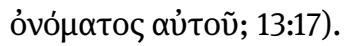

How does the seer then want the reader to decode this cipher? He makes an esoteric identification in 13:18 that actively initiates the hearers in the process

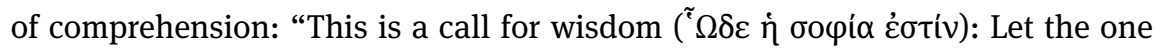
who has understanding calculate the number of the beast, for it is the number of a man [or: a human number; cf. Rev 21:17], and his number is 666" (cf. 17:911; Sib. Or. 5:28-29, 33-34). The number of the beast has been decoded in many ways, the most prevalent of which in modern scholarship is to understand it as a cipher for "Nero Caesar" based on the numeric value of transliterated Hebrew graphemes: Suetonius also records instances of bi-lingual (Latin-Greek) coded wordplay that circulated in regard to Nero's despatching of his mother (Nero 39.2). Regardless of identification, the text seeks the active participation of the reader, but the fundamental problem of textual variation makes the parameters of this event even more uncertain.

As we read the passage in Nestle-Aland ${ }^{28}$, we notice that the number at the end of the verse - $\dot{\varepsilon} \xi \alpha \kappa o ́ \sigma ı เ ~ \dot{\varepsilon} \xi \eta \dot{\eta} \kappa o v \tau \alpha ~ \check{\varepsilon} \xi$ - have angled brackets, denoting that the formulation is not entirely stable in the tradition. Based on the material in the apparatus, a collation of the reading looks like this ${ }^{15}$ :

14 For the range of possibilities, cf. D.E. Aune, Revelation, WBC 52b, 3 vols. (Nashville: Thomas Nelson, 1998), 2.770-73 and Craig Koester, Revelation, AYB 38A (London: Yale University Press, 2014), 596-99; G.K. Beale, The Book of Revelation, NIGTC (Grand Rapids: Eerdmans, 1999), 71828. Cf. also Jan Dochhorn, Schriftgelehrte Prophetie: Der eschatologische Teufelsfall in Apc Joh 12 und seine Beudeutung für das Verständnis der Johannesoffenbarung, WUNT 268 (Tübingen: Mohr Siebeck, 2010), 109-21, who argues forcefully that the sea beast should be identified with Nero; and Jan Willem van Henten, "Dragon Myth and Imperial Ideology in Revelation 12-13," in The Reality of Apocalypse: Rhetoric and Politics in the Book of Revelation, ed. D.L. Barr (Atlanta: Society of Biblical Literature, 2006): 181-203.

15 In addition to the list H.C. Hoskier, Concerning the Text of the Apocalypse, 2 vols. (London: Quaritch, 1929) offers some additional readings: 660 in GA 582 ( $\varepsilon \xi \alpha \kappa o \sigma \iota \alpha \varepsilon \xi \eta \kappa o v \tau \alpha)$ and a number of other abbreviations, many of which are scribal errors (2.364-265). Cf. also M. Lembke et al., eds. 


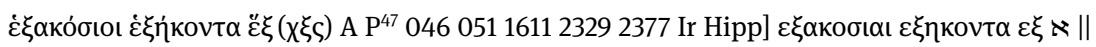

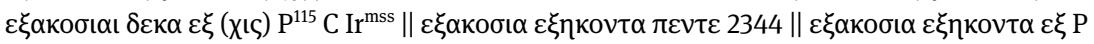
$1006184118542053^{\text {vid }}$

The apparatus indicates the existence of two major readings: 666 (including two sub-readings) and 616, which is preserved in only a few, but weighty witnesses. 665 is also preserved as a singular reading in GA 2344. The variation is central to the understanding of the passage, since the audience is asked to decode the beast narrative based on their knowledge of paranomastic practices, the world in which they live, and their ability to do basic arithmetic. The word play is the bridge between the text and their world or at least their world as the author perceives it.

Modern scholarship has approached this problem in one of two ways. First, some have simply asserted that one of the numbers, usually 666, is original and therefore the authentic arbiter of the tradition. ${ }^{16}$ This perspective suffers on a number of issues. Not only is the concept of "original reading” problematic, but the variant 616 is ancient, preserved in $\mathrm{P}^{115}$, Codex Ephraemi Rescriptus (C), and other witnesses. ${ }^{17}$ Irenaeus is also aware of the variant 616, even though he refers to it as an error and places the blame at the feet of copyists who were confused by the forms of abbreviation ( $\chi ı \varsigma$ and $\chi \xi \varsigma$; Adv. Haer. 5.30.1-3). For Irenaeus, using 616 to calculate the name of the beast (which he equates with the antichrist) is heretical (5.30.2). The earliest layers of interpretation identify the beast not as the menacing power of the Roman religious, political, and economic systems, ${ }^{18}$ but as an eschatological adversary, an idea carried into the commentaries of Oecumenius and Andrew of Caesarea. ${ }^{19}$

Text und Textwert der griechischen Handschriften des Neuen Testaments. VI. Die Apokalypse, ANTF 49 (Berlin: de Gruyter, 2017), 130-33 (hereafter TuT).

16 Also cf. D.C. Parker, "A New Oxyrhyncus Papyri of Revelation: P115 (P. Oxy. 4499),” NTS 46 (2000): 159-74 who expresses doubts about the certainty of 666 as the initial reading.

17 Other sources also preserve 616; for example, the Liber Genealogus (CPL 2254). For a fuller rehearsal of the versional data, cf. J. Neville Birdsall, "Irenaeus and the Number of the Beast: Revelation 13,18," in New Testament Textual Criticism and Exegesis: Festschrift J. Delobel, ed. A. Denaux (Leuven: Peeters, 2002): 349-59. On the reading in P115 specifically, cf. Zachary J. Cole, Numerals in Early Greek New Testament Manuscripts: Text-Critical, Scribal, and Theological Studies, NTTSD 53 (Leiden: Brill, 2017), 64-65, 192-94; Peter J. Williams, "P115 and the Number of the

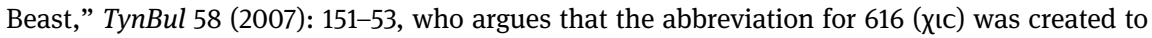
produce a greater graphic similarity between the number and the nomina sacra for Christ $(\chi \mathrm{c})$ or Jesus (ıc).

18 So Koester, Revelation, 599-601 and many others.

19 The name of kephalaia that comment on Rev 13:18 also identifies the figure as an antichrist

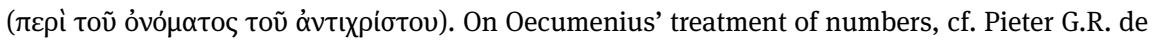
Villiers, "Numerical Symbolism in Oecumenius's Commentary on Revelation," in Tot sacra- 
Another approach has been to argue that the variant is the result of the process of decoding itself, especially when transliteration into Hebrew forms an integral part of the process. In this case, 616 was introduced into the tradition because קסר a more Latinizing form of "Nero Caesar" was transliterated into Hebrew as

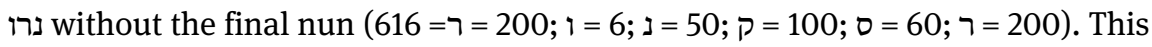
network of word play is all the more interesting since the word $\theta$ píov ("beast"; cf. 13:1), when transliterated to Hebrew (תריון), also adds to $666 .^{20}$

The data in the apparatus of Nestle-Aland ${ }^{28}$ proves invaluable in assessing the tradition, offering a healthy number of variants, even singular readings and morphological deviations. The editors realised that the wording of the tradition in this unit would be of great interest because it has direct exegetical consequence for how historical-critical exegetes reconstruct the world which the Apocalypse was designed to address, in addition to the fact that the identification of a historical figure might help date the production of the work. The edition provides fruitful grounds for historical-critical discussion.

But it does not offer a deeper level of access to the tradition. Interest in the name of the beast extends back to the earliest commentators as I mentioned above, interest that has shaped all pre-critical engagement with this passage. For example, Irenaeus offers three Greek names whose graphemes equate to 666 (EYANOA $\Sigma, \Lambda$ ATEINO $\Sigma$, and TEITAN) in an effort to quell unrestrained interest. Neither EYAN $\Theta A \Sigma$ nor TEITAN are the names of rulers, although $\Lambda$ ATEINO $\Sigma$ might be of interest since it corresponds to the fourth kingdom in Daniel 7, since the Latins (= Rome) are currently ruling (Adv. Haer. 5.30.3; cf. Hippolytus De Ant. 50). This name also carried special significance in the later Byzantine empire. In spite of the surfeit of information in the apparatus, the hand edition barely scratches the surface of other information that lurks in Revelation's manuscript witnesses and history of interpretation. To understand more fully the way that the manuscript tradition of the Apocalypse received its own text in conversation with the broader tradition, we need to examine further every witness of the book of Revelation that preserve marginal comments or paratextual emphasis on Rev 13:18 to see how the expressive features of these forms speak to the practices of interpretation active in the contexts in which they were produced and read.

The manuscripts that preserve marginal comments can be grouped into three traditional streams, although there are obvious overlaps between them and

menta quot verba: Zur Kommentierung der Apokalypse des Johannes von den Anfängen bis ins 12. Jahrhundert, ed. K. Huber, R. Klotz, and C. Winterer (Münster: Aschendorf, 2014): 135-52.

20 Cf. Aune, Revelation, 2:769. 
variations internal to each. None of these witnesses are particularly venerable in terms of their text and all are medieval or early modern, but they comprise an important group that arbitrates interpretive information on a difficult passage.

\section{Irenaeus Traditions}

As the earliest known commentator on Rev 13:18, Irenaeus' influence is visible across each of these other streams that transmit marginal comments. However, only two manuscripts explicitly point to Irenaeus as their traditional source. GA 1859 (Athos, Kutlumusiu 82; fourteenth century) ${ }^{\mathbf{2 1}}$ preserves a conventional form of the text of Rev 13:18. More interesting is the note that appears at the lower margin that is connected to 13:18 via matching supralinear glyphs located above

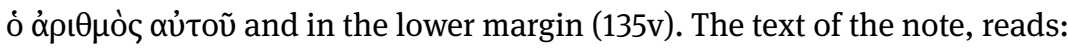

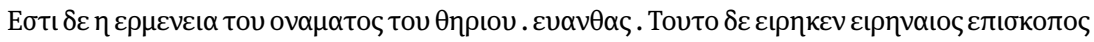

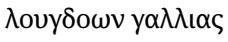

And here is the interpretation of the name of the beast: Euanthas, because this was explained by Irenaeus Bishop of Lugdunum in Gaul

The note, included by the initial copyist of the manuscript, identifies the name of

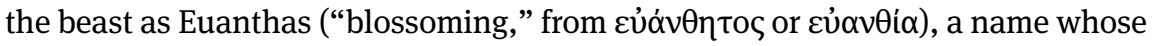
Greek graphemes equate to 666 when assigned numeric values. By making explicit its connection to Irenaeus, the note demonstrates the influence of this tradition as a perduring and authoritative intertext for Rev 13:18. Furthermore, it is interesting that the note keys on Euanthas because Irenaeus himself notes that "for the name Evanthas contains the required number, but I make no allegation regarding it" (sed nihil de eo affirmamus). Instead, Irenaeus prefers Titan (TEITAN) because of its ancient pedigree, royal dignity, and tyrannical implicature, although he demurs at identifying the antichrist's name with certainty (Adv. Haer. 5.30.3).

The note in 1859 is valuable insofar as it mediates between the interpretation of the Apocalypse and the interpretation of Irenaeus in the Middle Ages (although it does not betray a close reading of Irenaeus) and interest in decoding the name of the beast, who by this time did not represent a Roman emperor of old, but an eschatological figure yet to come. For good reason the editors of Nestle-Aland ${ }^{28}$ omitted this material: it does not quote the text of the Apocalypse, it is an idiosyn-

21 Cf. Spyr. P. Lambros, Catalogue of the Greek Manuscripts on Mount Athos (Cambridge: Cambridge University Press, 1895), 1:281 (3151). 
cratic witness to Irenaeus, and it is preserved in a late copy that is not textually interesting enough to be utilised as a "consistently cited witness." 1859 corresponds closely to the Koine text form, ${ }^{22}$ one of Revelation's two Byzantine textual traditions.

The same holds for GA 2027 (Paris, BnF, gr. 491, thirteenth century) whose text is also closely aligned with the Koine tradition (Fig. 1). This witness preserves an identical note to the one in 1859, added into the right margin by a later hand who also made selective comments on other texts.

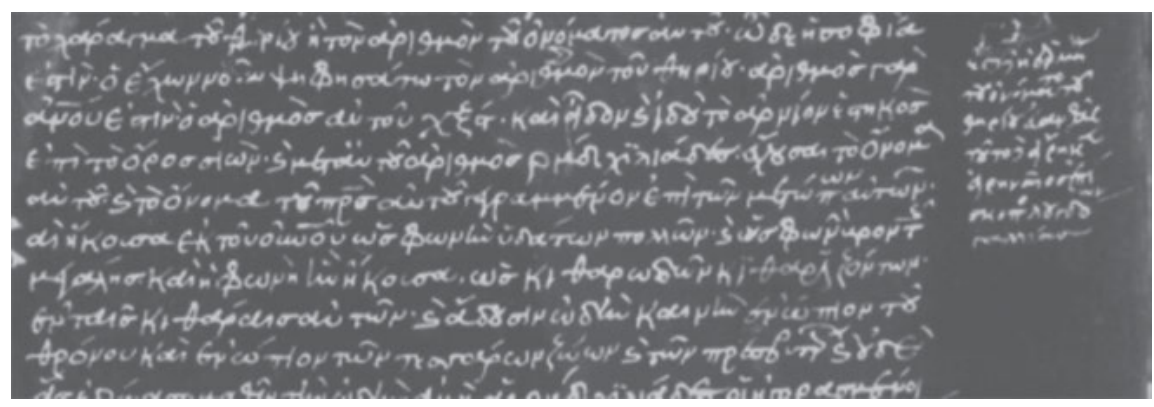

Fig. 1: GA 2027 (Paris, BnF, gr. 491), Comment on Rev 13:18 (289r). With permission of the Bibliothèque national de France.

Neither 1859 or 2027 boast extended commentary or catena apparatuses and the identity of the beast receives special attention, decoding the name by appeal to one of Irenaeus' possible options. Despite the lack of textual importance of these witnesses, they remain valuable for those interested in the reception of Irenaeus or in the interpretive history of Rev 13:18. Beside combing through digitised images of every manuscript and out-of-print philological works, how else is one to access this material? What other reservoir of information might archive such a scribal note? The answer that I will inevitably give is the digital edition, but there is more material to examine first.

\section{Oecumenius and Andrew of Caesarea Traditions}

The most prevalent form of paratextual comment on Rev 13:18 is closely related to the commentary tradition of Oecumenius, which was adopted and further devel-

22 TuT, 553. 
oped by Andrew of Caesarea in the late sixth or early seventh century. These comments are located in thirty-two manuscripts and fall into three main categories. The first and largest body are excerpts taken directly from the Andrew of Caesarea commentary, although they often differ in their wording, reflecting the high level of textual variation within the Andrew text. ${ }^{23}$ For example, take GA 1732 (Athos, Lavra, A 91; copied in 1384; Fig. 2), which preserves the following notation in the lower margin ${ }^{24}$ :

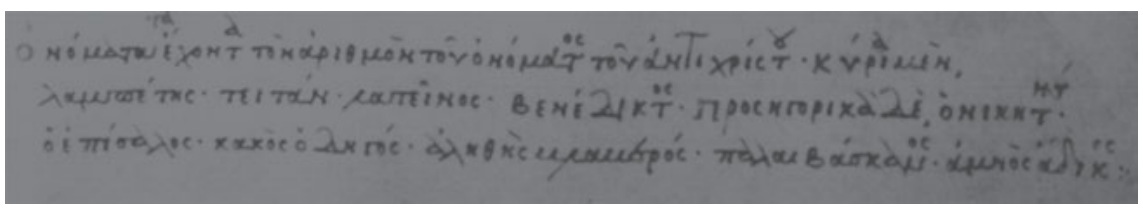

Fig. 2: GA 1732 (Athos, Lavra, A 91) comment on Rev 13:18 (detail, lower margin). Public Domain: Library of Congress Collection of Manuscripts from the Monasteries of Mt. Athos.

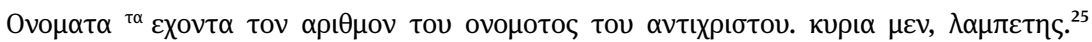

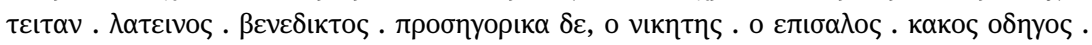

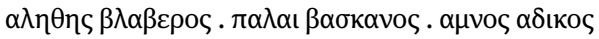

Names of those that have the number of the name of the antichrist: First, proper nouns: Lampetis, Titon, Lateinos, Benedict. Second, common nouns: The Conqueror; the Rough One; Wicked Guide; True Harm; Ancient Slanderer; ${ }^{26}$ Unjust Lamb.

This text extracts all the possible formulations that add to 666 offered by Andrew

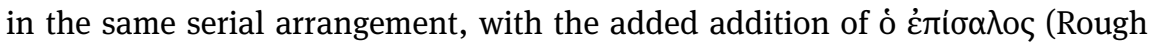

23 Cf. the apparatus of J. Schmid's edition Studien zur Geschichte des griechischen ApokalypseTextes (Munich: Karl Zink, 1955), 144-46. On the interpretation of the Andrew commentary, cf. Juan Hernández, Jr., "Andrew of Caesarea and His Reading of Revelation: Cathechesis and Paranesis," in Die Johannesapokalypse: Kontexte - Konzepte - Rezeption, WUNT 287, ed. J. Frey, J.A. Kelhoffer, and F. Tóth (Tübingen: Mohr Siebeck, 2012), 755-74; Eugenia Scarvelis Constantinou, Guiding to a Blessed End: Andrew of Caesarea and his Apocalypse Commentary in the Ancient Church (Washington, D.C.: The Catholic University of America Press, 2013); Georg Kretschmar, Die Offenbarung des Johannes: Die Geschichte ihrer Auslegung im 1. Jahrtausend (Stuttgart: Calwer, 1985), 80-90.

24 GA 32520592259 retain nearly identical texts in their notes.

25 The word totals 666 if spelled $\lambda \alpha \mu \pi \varepsilon \tau$ เ .

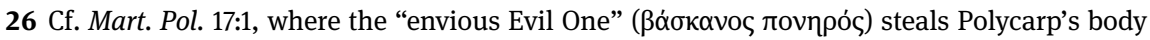
after his immolation. 
One), which is found in Oecumenius. ${ }^{27}$ There are multiple interesting features of this note that shed further light on the reception history of the passage, features that are routinely omitted from critical editions for a host of legitimate reasons. First, the scribe responsible for this note identifies the beast as the antichrist, the eschatological foil of the lamb, following traditional precursors like Irenaeus and Hippolytus. The antithetical parallelism between the beast and the lamb (cf. Rev 5:5-7) is further amplified by the final name in this list, Unjust Lamb, indicating that the tradition here is aware of the broader contours of Revelation's narrative and use of antithetical characters. ${ }^{28}$

While the sum of the names taken from the Andrew commentary equate exactly to 666 , the scribe is not so fastidious in his arithmetic and/or copying. All of the names as copied are within the ballpark of 666, but many are divergent.

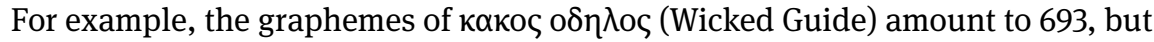

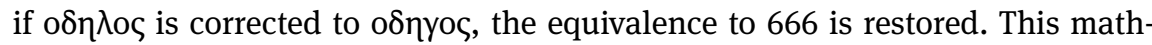
ematical digression suggests that the scribe did not necessarily understand the principles of the inherited tradition.

This exemplar emphasises the importance of Rev 13:18 as a location of intense exegetical activity. The material layout of the leaf points in this direction through the presence of paratextual markers (heavy dots) that bracket the verse in the text and the marginal notation, both of which cannot easily be embedded in conventional print editions. Additionally, both of these features are not expressly textual insofar as they implicitly interpret the text of Rev 13:18 without functioning as witnesses to the text themselves, only to traditions of interpretation.

A second subsection of the commentary stream is represented by witnesses that simply list the proper names listed in the Andrew commentary, and sometimes other traditions. These lack explicit attribution and the relationship between them and the text is assumed. For example, GA 1865 (Athos, Philotheu 38, thirteenth century), a witness to Revelation's Complutensian textual traditions, preserves the four proper names in the Andrew commentary ${ }^{29}$ :

27 The Oecumenius tradition also adds ò vıкптท́ (the Conqueror) as an option. Cf. Marc de Groote, ed. Oecumenii Commentarius in Apocalypsin, TEG 8 (Leuven: Peters, 1999), 192-93. Cf. also Andrew's similar list of names ascribed to Jesus in his commentary of Rev 19:12b (keph. 58), although these names are not paranomastic or tied to the numerical value of Greek graphemes. 28 For more on antithetical characters, cf. Richard Bauckham, The Climax of Prophecy: Studies on the Book of Revelation (Edinburgh: T\&T Clark, 1993), 174-98.

29 Identical traditions appear in GA 1768 and 2723, and other manuscripts contain only single

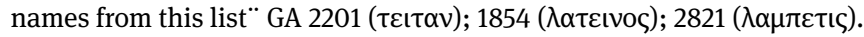




\author{
$\lambda \alpha \mu \pi \varepsilon \tau \eta \varsigma^{30}:$

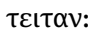

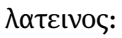

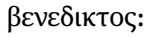 \\ Lampetis \\ Titan \\ Latin \\ Benedict
}

These four names, the graphemes of which (with the exception of the uncorrected form of $\lambda \alpha \mu \pi \varepsilon \tau \eta$, "Arsonist") add up to 666, are also part of the list of names in 1732 and it incorporates two of the three names that Irenaeus mentions in $A d v$. Haer. 5.30.3. But other lists preserve other proper names. The list in the lowerright margin of GA 468 (Paris, BnF gr. 101, thirteenth century) lists five names, including two not mentioned 1865: $\pi \varepsilon \rho \sigma \alpha ı$, whose graphemes only add to 656, and the Irenaen $\varepsilon v \alpha v \theta \alpha \varsigma$, along with $\tau \varepsilon ı \tau \alpha v, \lambda \alpha \tau \varepsilon ı v o \varsigma$, and $\beta \varepsilon v \varepsilon \delta$ เктоৎ. GA 1685 (Athens, Byz. Mus. 155), a manuscript with a handful of marginal scholia, adds other proper names not yet found in other witnesses, including عvivas ("of stout fibres;" "strongly built"), $\chi \alpha \iota \varepsilon v(666),{ }^{31}$ and $\sigma \alpha \rho \mu \varepsilon v \alpha \iota \circ$ (677), ${ }^{32}$ names that do not correspond to any known commentary on Revelation. It seems that the tradition inaugurated by Irenaeus of using the numerical value of Greek graphemes to determine the identity of the beast continued, sparking imaginative engagement with the text that led to creation of additional onomastic options, even if their meanings remain obscure.

But the lists expand further, drawing on the material in the Andrew commentary, both the proper names and adjectival formulations, as well as other sources. GA 2073 (Athos, Iviron, 273; copied in 1316) is a copy of the Andrew commentary, copied on 157 leaves, attached to a copy of a work by John Chrysostom (Fig. 3). It contains some additions and marginal comments from other sources, including Irenaeus, Hippolytus, and the Oecumenius commentary. ${ }^{33}$ Among these include a ten-item list of names whose graphemes equal 666, located in the upper left margin of the leaf after the lemma that contains Rev 13:18.

$30 \lambda \alpha \mu \pi \varepsilon \tau \iota \varsigma=666$.

31 A corrupt form of $\chi 0$ ó $\omega$ "to bury”?

32 For $\sigma \alpha \rho \mu \varepsilon v o \varsigma$ (666), from $\sigma \alpha \rho \mu \varepsilon u ́ \omega$, "to dig sand”?

33 Cf. Schmid, Studien, Einleitung, 27-28. 


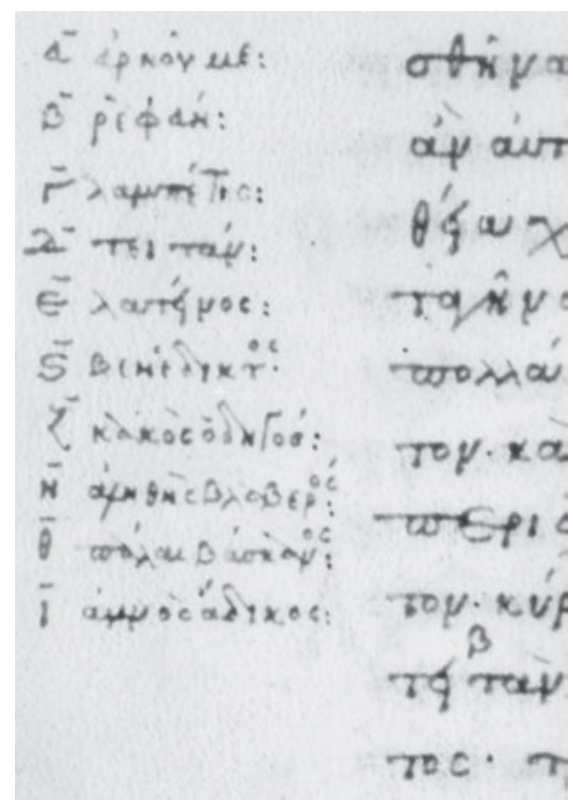

Fig. 3: GA 2073 (Athos, Iviron, 273), Comment on Rev 13:18 (73v). Public Domain: Library of Congress Collection of Manuscripts from the Monasteries of Mt. Athos.

$\alpha \alpha \rho v o v \mu \varepsilon:$

$\beta \rho \varepsilon \varphi \alpha v:$

ү $\lambda \alpha \mu \pi \varepsilon \tau \iota \varsigma:$

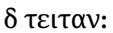

$\varepsilon \lambda \alpha \tau \varepsilon$ IVoৎ:

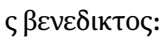

$\zeta$ како обпуо५:

$\eta \alpha \lambda \eta \theta \eta \varsigma \beta \lambda \alpha \beta \varepsilon \rho \circ$ :

$\theta \pi \alpha \lambda \alpha \mathrm{s} \beta \alpha \sigma \kappa \alpha$ vо:

ı $\alpha \mu \nu о \varsigma \alpha \delta$ เко५:-

1. Arnoume

2. Rephan

3. Lampetis

4. Titan

5. Latin

6. Benedict

7. Wicked Guide

8. True Harm

9. Ancient Slander

10. Unjust Lamb

Many of these names and titles (3-10) are drawn directly from the Andrew commentary, but two new proper names head this list that have been hitherto unknown, the second of which ( $\rho \varepsilon \varphi \alpha v)$ adds to 656, although as minor mor- 
phological change ( $\rho \varepsilon \iota \varphi \alpha v)$ solves this issue. This name is drawn from Amos 5:26, a passage that critiques Israel's cultic devotion to foreign gods, contrasting their faithfulness in the time of wilderness wanderings to their current infidelity. GA 051 (Athos, Patonkratoros, 44, tenth century, Fig. 4), the earliest witness to marginal comments on Rev 13:18, connects the beast explicitly to the text in Amos.

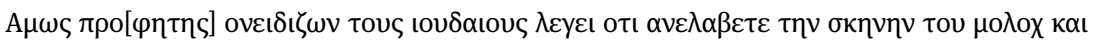

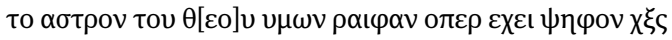

Amos the prophet reprimanded the Jews. He said that you took up the tent of Moloch and the star of your God Raiphan, which calculates to 666.

Of all the marginal notes, this is the only one that explicitly identifies an intertext embedded within Revelation, a notoriously allusive text. Despite the fact that the spelling of Raiphan in this note only equates to 662, the scribe responsible for the note and catenae in the manuscript responded to the compositional features of Revelation to make an obscure connection to Amos. This connection, like the other names identified in these notes, is based on the numerical value of the sum of the Greek graphemes in a given appellation.

The name Arnoume ("deny me") appears as an option in the work De consummation mundi (28) of Pseudo-Hippolytus, ${ }^{34}$ and this descriptive name appears alone adjacent to Rev 13:18 in the margin of a number of manuscripts, almost as a mantra for warding off the antichrist. ${ }^{35}$ Although the form of this marginalia differs from the preceding examples in terms of form (enumerative list), it functions identically by connecting Rev 13:18 to traditions of its interpretation. The list also appears to be innovative based on the paratexts that appear in the commentary. The names that appear in the accompanying Andrew commentary preserved in this manuscript are denoted with supralinear Greek numerals, numerals that differ from those in the list. This page in GA 2073 preserves two competing, but overlapping lists: one in the margin and one in the commentary text.

Many other witnesses in this strand preserve similar lists to the one located in 2073, along with other traditional catenae, and even attribute the material to

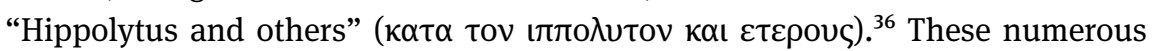
instances of related marginal comments represent a broad body of evidence, with its own internal textual variation, that speaks to medieval perceptions of

34 Cf. Hans Achelis, Hippolyt's kleinere exegetische und homiletische Schriften (Leipzig: Hinrichs'sche, 1897), 301.

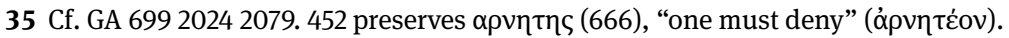

36 GA 357578241072107512481503155115971637174017451771186420412254235224312554. 


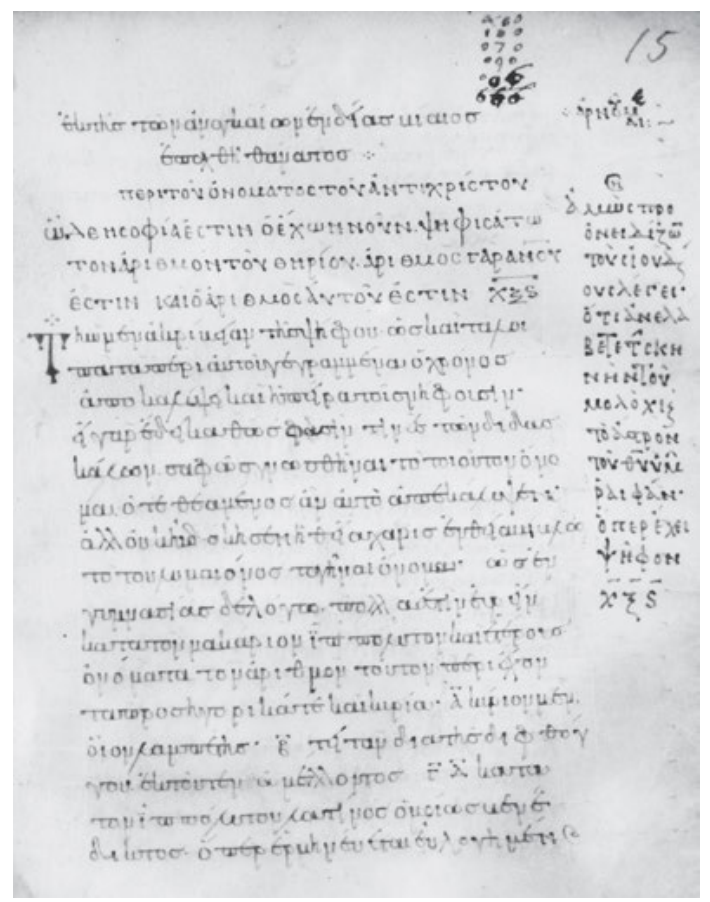

Fig. 4: GA 051 (Athos, Pantokratoros 44) comment on Rev 13:18 (15r). Public Domain: Library of Congress Collection of Manuscripts from the Monasteries of Mt. Athos.

the importance of Rev 13:18. It also confirms that the Andrew of Caesarea tradition is the dominant channel of tradition for the interpretation of the Apocalypse in this period since the majority of this material is traceable back to this commentary. Even those examples that mention Hippolytus do so because Andrew himself quotes him explicitly. Before commenting on how a digital edition might incorporate this material and thus increase the editorial flexibility and reception historical value of such a digital artefact, other relevant examples should be highlighted.

\section{Conflicts with Muhammad and Islam}

A third strand of the tradition of comment on Rev 13:18 deals with anti-Islamic sentiments. These comments offer insight not only into traditions of interpretation further untethered from ancient and late antique interpreters, but also 
into the historical pressures and existential threats that these communities mostly monastic, Orthodox, and located in Greece - perceived in the waning fortunes of the Byzantine empire. These communities were threatened both by Ottoman political ascension and also by the influence of western Latin Christianity under the auspices of papal power, especially following the sack of Constantinople in 1204 by the Fourth Crusade. ${ }^{37}$ Eschatological tensions increased in the late Byzantine period as many saw the growing threat from Islamic groups in the east as an omen of the impending eschaton and theological influence of the Latin church (and threat of unification in the thirteenth century) as evidence of a larger cosmic struggle between orthodoxy and heresy. ${ }^{38}$ In this context, interest in Revelation as a work increased dramatically. Over seventy percent of all of Revelation's Greek manuscripts were copied from the thirteenth century onward, spiking following the events of 1203 and the fall of Constantinople to the Ottomans in 1453 (see Table 1). And this is coupled with the fact that although only three Greek commentaries on the Apocalypse had been composed in late antiquity (Oecumenius, Andrew, and Arethas), eleven were produced in the post-Byzantine period between 1600 and 1800, not even considering the numerous works devoted to the exposition of the Apocalypse that were composed during the late Byzantine empire. A primary focus of many of these writings is the interpretation of the two beasts, which appear in Revelation 13, an exegetical emphasis that spills out into the margins of particular manuscripts. ${ }^{39}$ Like the notes located in the following manuscripts, these traditions, diverse though they are, tend to interpret Rev 13:18 as the identity of the antichrist, who is either the papacy, Muhammad, or both.

A first example of this type of interpretation is located in GA 1778 (Thessaloniki, Vladaton, 35, fourteenth-fifteenth century), a double commentary that includes material from both the Andrew and Oecumenius commentaries. ${ }^{40}$ The comment here appears on the page after the lemmatic text of 13:18, attaching itself to the commentary text (98r).

37 On the messianic and eschatological pressures of the period, cf. Asterios Argyriou, Les exégèses grecques de l'Apocalypse à l'époque turque (1453-1821): Esquisse d'une histoire des courants idéologiques au sein du people grec asservi (Thessaloniki: Kronoz, 1982), 9-124. An espe-

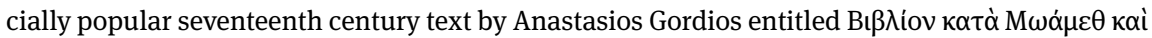
$\lambda \alpha \tau i v \omega v$ (Book against Muhammad and the Latins) adequately expresses these dual pressures posed by Ottoman hegemony in the east and the Latin church in the west.

38 Cf. Michael Angold, "Byzantium and the west 1204-1453," in The Cambridge History of Christianity: Eastern Christianity, vol. 5, ed. M. Angold (Cambridge: Cambridge University Press, 2008): 53-78.

39 Cf. Argyriou, Les exégèses grecques, 113-24.

40 Cf. Schmid, Studien, Einleitung, 64-66. 


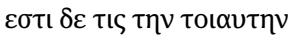

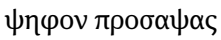

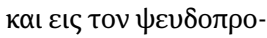 \\ $\varphi \eta \tau \eta \nu \mu \omega \alpha \mu \varepsilon \theta$. $\varepsilon-$ \\ $\xi \varepsilon \lambda \eta v i \zeta o \mu \varepsilon v o \varsigma$ $\gamma \alpha \rho$ \\ $\mu \alpha \mu \varepsilon \tau \mathrm{\tau} о \mathrm{~s} \lambda \varepsilon \gamma \varepsilon \tau \alpha \mathrm{t}$.

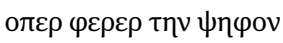

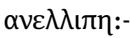

For it refers to the calculation of those also attached to the false prophet Muhammad. For in Greek he is called Mametios. The calculation lacks nothing.

Like the preceding streams, this note identifies the number of the beast as a name, but in this case it is not tied directly to a name $(\mu \omega \alpha \mu \varepsilon \theta)$, but a latinized Greek transliteration of the name ( $\mu \alpha \mu \varepsilon \tau ו o \varsigma)$ which not coincidentally totals 666. Moreover, unlike the other lists that include names unattached to any particular historical figure, this example identifies Muhammad as the antichrist, demonstrating a rejection of Irenaeus' caution in identifying a particular figure. The stakes of this exegesis are much higher. ${ }^{41}$

GA 2077 (Athos Iveron 644; copied in 1685) also carries a similar reading,

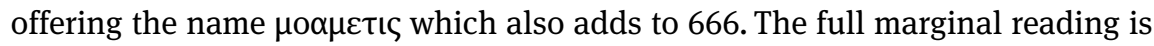

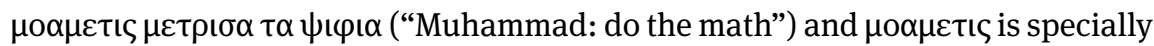
emphasised by ornamental penwork frames. The first leaf of this manuscript also

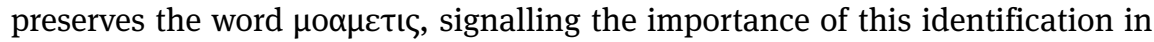
the context of the manuscript's production. Muhammad was on the mind of our copyist. Again, like the other examples, the concern does not seem to be an effort to understand the beast within the first century world, but to create a decoded synecdoche for Islam by appealing to the name of the prophet. The identification of a specific person increases the eschatological pressure of the text - if Muhammad is the antichrist then the end of the age in certainly nigh.

The association of Muhammad with the beast further illustrates the ways in which Christian communities understood their present through the lens of scriptural interpretation. The threat of Islamic political domination posed an existential threat to the community, and therefore could be identified with

41 Byzantine resistance to Islam and its prophet precedes the presence of these notations by many centuries. Cf. Argyriou, Les exégèses grecques, 17-25, especially the practical reasons to emphasise the tradition of Muhammad as anti-Christ: "L'image de Mahomet-Antichrist et du règne de l'Islam-règne de l'Antichrist était effectivement de natur à frapper l'esprit des simples fidèles, à freiner les conversions et à contenir la collaboration avec les ennemis du Christ” (p. 24). 
Table 1: Chronological Distribution of Revelation's Greek Manuscripts.

\begin{tabular}{lr}
\hline Century & Number of Witnesses \\
\hline$I I$ & 1 \\
\hline$I I I$ & 1 \\
\hline$I V$ & 7 \\
\hline$V$ & 4 \\
\hline VI & 0 \\
\hline VII & 1 \\
\hline VIII & 1 \\
\hline$I X$ & 1 \\
\hline$X$ & 14 \\
\hline$X I$ & 35 \\
\hline$X I I$ & 28 \\
\hline$X I I I$ & 29 \\
\hline$X I V$ & 69 \\
\hline$X V$ & 59 \\
\hline$X V I$ & 43 \\
\hline$X V I I$ & 15 \\
\hline$X V I I I$ & 5 \\
\hline$X I X$ & 2 \\
\hline
\end{tabular}

Cf. TuT, 2-22.

one of Revelation's beasts. This note identifies a specific historic person, in contrast to the previous streams, but its method of identification is identical to that of Irenaeus or Andrew: decoding based on the numerical value of Greek graphemes.

Another manuscript in this strand is GA 2075 (Athos, Iviron, 370, fourteenth century), a commentary manuscript that contains additional layers of marginal comments by later hands. In line with the preceding example, it too identifies the beast as $\mu$ о $\mu \varepsilon \tau \iota \varsigma$ and encourages the reader to do the math. Its text is similar to GA 2814 (Augsburg, Univ. Bib. I.1.4.1, twelfth century), a copy of the Andrew commentary, that preserves a partially cut off note by a later hand.

This note in 2814 identifies the word $\mu \alpha \chi \kappa \varepsilon$ (from $\mu \alpha \chi \alpha \dot{\alpha} \omega$, "to fight", or perhaps a reference to Mecca), which corresponds to 666, as an interpretation

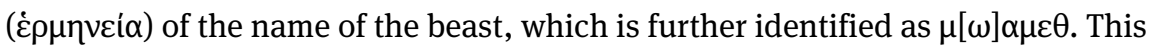
witness to the anti-Islamic strand of interpretation does not rely on the Latinised form $\mu о \alpha \mu \varepsilon \tau \iota \zeta$, but uses an alternative form that corresponds to the scribe's 
perceptions of a characteristic of Islam, a perception undergirded by Ottoman advances in Asia Minor and the Aegean in the fourteenth century, perhaps also referring to Mecca. Regardless of mathematical strategy, some readers of Revelation were intent on seeing coded reference to Muhammad in the New Testament.

Other subtler forms of anti-Islamic interpretations co-mingle with other traditions. GA 2072 (Athos, Dochiariu, 81, copied in 1789), a commentary manuscript that preserves evidence of editorial intervention by readers over a period of time,

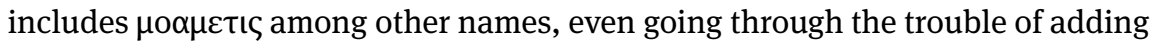
up the value of the graphemes in Arabic script (fol. 413).

It also includes $\beta \varepsilon v \varepsilon \delta$ เктоৎ and $\lambda \alpha \tau \varepsilon$ เvoৎ, names found in Irenaeus, as well as

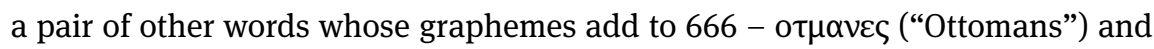

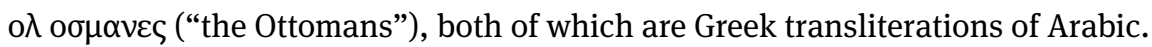
Although from a much later period, the juxtaposition of $\lambda \alpha \tau \varepsilon$ เvos ("Latin") with

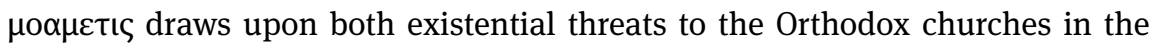
Byzantine commonwealth in the twelfth to the fifteenth centuries. In fact, the greatest perceived threat to the prestige of the Athonite monasteries in particular was not Islamic ascendency in Asia Minor - even though the monasteries were occasionally beset by Saljuk raiders and some of the monks had previously taken part in military campaigns in the Levant ${ }^{42}$ - but in the potential of political alliance with the Latin west, especially following the sacking of Constantinople in 1204. In some corners of Byzantine society, the fall of Constantinople in 1453 was even viewed as divine judgement on attempts to unify Orthodoxy and Catholicism..$^{43}$ The publication of numerous lists of the "errors of the Latins" emphasizes the serious perceived theological differences between Christian communities under Roman and Constantinopolitan spheres of influence. ${ }^{44}$ The monasteries benefitted from and actively sought out Ottoman protection, and many Christians in the fading Slavic and Russian Byzantine commonwealth donated their estates to the monasteries in an effort keep their wealth within Christian circles of influence. The population of Athonite monasteries also grew in this period as adherents sought to avoid military service. The monasteries thrived in a period of interreligious conflict. Therefore, the identification of Muhammad as the antichrist in this setting is somewhat counter-intuitive in light of the influx of wealth to the monasteries after the fall of Constantinople, and the political alliance of

42 E.g. Peter the Athonite, a ninth-century monk who was once imprisoned in Samara. Cf. Kirsopp Lake, The Early Days of Monasticism on Mount Athos (Oxford: Clarendon, 1909), 8-39.

43 Angold, "Byzantium," 78.

44 Cf. Tia M. Kolbaba, The Byzantine Lists: Errors of the Latins (Chicago: University of Illinois Press, 2000). 
the Orthodox patriarchate in Constantinople with the Ottoman sultans. ${ }^{45}$ This specific interpretation of Rev 13:18 did not necessarily reflect the monastics politics of compromise and protection with Ottoman authorities.

A similar pattern is found in GA 1775 (Athos, Panteleimonos, 100, copied in 1847), which is perhaps the latest non-typographic copy of Revelation and the Andrew commentary in existence $(135 \mathrm{v}){ }^{46}$

This manuscript preserves a number of tortured calculations and creative attempts to decode the name of the beast. In addition to $\lambda \alpha \tau \varepsilon$ เvos, the scribe

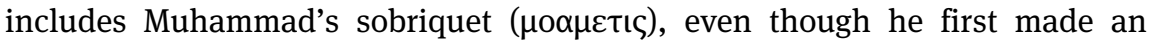
error in spelling the name. Other names like $\mu \varepsilon \tau \zeta ı \tau \delta$ whose graphemes add to 666 are included, referring to the contemporary Ottoman sultan Abdulmejid I

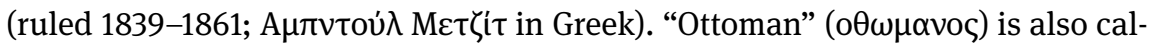
culated even though it adds to 1240. Despite its singularities, this manuscript shows that a consistent tradition from Irenaeus to the nineteenth century existed in which readers of the Greek text were intent on reading the name of the beast as a paranomastic game that concealed the name of the Antichrist, especially when those names could be tied to opponents of Orthodoxy in the Latin west or their Ottoman patrons. Ancient traditions remained venerable, but were also supple enough to take on contemporary concerns and events. Readers relied heavily on the interpretations of Christian antiquity, but also showed various forms of development, especially in the repeated identification of Muhammad and even their Ottoman patrons as eschatological figures. Interreligious conflict, uneasy political alliances, and fear of the other are deep-seated parts of the Christian interpretive imagination, obvious traces of which still exist in many corners of the modern world.

In each these examples of marginal notes that decode the identity of Revelation's beast, it is always equated with the eschatological adversary of God's people - an identification that is not necessarily obvious in the text itself, especially since the majority of modern interpreters attempt to decipher 666 in a way that equates to a Roman ruler from the first century. Each note, however, represents

45 Cf. Elizabeth A. Zachariadou, "Mount Athos and the Ottomans c.1350-1550," in The Cambridge History of Christianity: Eastern Christianity, vol. 5, ed. M. Angold (Cambridge: Cambridge University Press, 2008): 154-68; eadem “The Great Church in captivity 1453-1586," in the same volume, pp. 169-86.

46 The lemmatic text of the manuscript is abbreviated. 
traditions that respond to the text's call for reader participation. Scribes record Greek names whose grapheme sums equal 666 or thereabouts. None of these examples resort to interlinguistic gematria, but focus only on Greek equivalents or sobriquets in the cases of Muhammad and Abdulmejid. This fact highlights the ingenuity of modern scholarly attempts to solve this riddle that focus on identifying a first century Roman emperor instead of an eschatological antagonist. These interpreters were not apparently seeking to identify a historical antagonist or emperor, but instead an eschatological figure that remained relevant in their historical context. Using traditions from Irenaeus, Hippolytus, and Andrew as a platform, these comments embedded names into the margins of documents that preserve Revelation in an effort to warn readers that rulers with these names might be dangerous. These types of "prophetic" decoding of Revelation's imagery are not solely the propriety of modern fundamentalist eschatological hermeneutics.

Dating from the tenth to the nineteenth centuries and clustered in the eastern Mediterranean - particularly in Greek Orthodox monasteries - the material evidence emphasises the local nature of this tradition, as well as the influence of Orthodox monasticism and exegetical commentaries and other works of this period that focus on the identity of the antichrist, illuminating particular reading cultures and accentuating the mediated nature of scriptural interpretation. ${ }^{47}$ These traditions represent dominant ways of reading Rev 13:18, especially if we consider that numerous other commentary manuscripts include detailed analysis of this text as basic parts of their composition. This information provides insight into the hermeneutics that controlled interpretations of the Apocalypse. This melding of interpretation and textual witnesses in the material culture that encompasses a work's transmission reinforces again the idea that textual history and reception are integrally linked and that critical editions can potentially serve as the medium for melding these parallel facets of a work, especially editions that are as comprehensive as feasible in providing access to the documentary facets of the tradition regardless of the textual value - or lack thereof - of each witness.

47 For example, the post-Byzantine commentary by Christophoros Anghelos (b. 1575) argues forcefully, from many texts including Rev 13:18, that Muhammad is the antichrist, not the Pope, although the Pope is identified as the first beast in Revelation 13. Cf. Argyrou, Les exégèses grecques 227-42. 


\section{The Beast and Digital Editions}

Admittedly, the marginal notes and images analysed in the preceding section are a persistent, but secondary concern in the big picture of constructing a workable and economically viable critical edition. However, these traditions are important for reception historians and philologists who grapple with manuscripts not merely as text-receptacles, but as cultural artefacts with expressive power. These types of features provide insight not only into reception history, but channels of textual transmission and the mediums through which interpretive traditions are mediated. A major dissatisfaction with common hand editions of the New Testament, when compared with the theorised possibilities of digital texts, is that the peculiarities of these witnesses are lost, due in large part to the herculean task of sifting through the variants offered by thousands of diverse witnesses. But the turn to digital editions and the drive to digitally transcribe witnesses offers an opportunity to rethink the boundaries of the edition without harming the overriding goal of constructing a workable text and textual history. ${ }^{48}$ In fact, the digitalness of the edition also enhances textual studies by potentially allowing users to shape the evidence presented. Hugh Houghton and Catherine Smith note that "electronic publishing... allows much more freedom, with the potential for users to customise their views, such as toggling between a positive and negative apparatus, or selecting different witnesses for inclusion." ${ }^{49}$ Not only can readers recombine text and artefact, but they can manipulate the textual rhetoric of the edition.

Let us take as a concrete example the ECM of the Apocalypse that is being constructed by Martin Karrer and his team in Wuppertal, Germany. ${ }^{50}$ The project is currently designed to be born digital, meaning that every stage, from image aggregation to transcription to reconciliation to apparatus construction,

48 The turn toward digital text has since the 1990s led to a large-scale reappraisal of the materiality of print and manuscript cultures, and not just in biblical studies. The literature of this discourse is vast, but see especially N. Katherine Hayles, Writing Machines (London: MIT Press, 2002), 22-33 whose work on digital texts has led her to conceive of books as "material metaphors": "the physical form of the literary artifact always affects what the words (and other semiotic components) mean” (p. 25). See also McGann, Radiant Textuality, 1-19.

49 H.A.G. Houghton and Catherine J. Smith, "Digital Editing and the Greek New Testament," in Ancient Worlds in Digital Culture, ed. C. Clivaz et al. (Leiden: Brill, 2016): 111.

50 Cf. project reports in U. Schmid, "Die neue Edition der Johannesapokalypse. Ein Arbeitsbericht," in Studien zum Text der Apokalypse, ANTF 47, ed. M. Sigismund, M. Karrer, and U. Schmid (Berlin: de Gruyter, 2015): 3-15; M. Sigismund, "Die neue Edition der Johannesapokalypse: Stand der Arbeiten," in Studien zum Text der Apokalypse II, ANTF 50, ed. M Sigismund and D. Müller (Berlin: de Gruyter, 2017): 3-17. 
is fully integrated in a digital format. Any printed edition that results from the project will be entirely derivative of the project's electronic content. Much has already been said about the process of digital editing of the ECM, especially by H.A.G. Houghton and D.C. Parker. ${ }^{51}$ However, I am not interested necessarily in the process of editing, but in the value of using a digital platform.

First, I should note that the ECM of the Apocalypse is revolutionising critical editions of the New Testament due to the quantity of textual and material data that have been aggregated in the process of transcription. The project has chosen to transcribe not only the text of the manuscripts, but also a variety of paratextual features, including corrections, running titles, capitals, ekthesis, rubrication, structural features (line and column breaks), kephalaia, marginal notes, and artwork among others. The manuscripts are transcribed and reconciled in XML format. ${ }^{52}$ This means that at the end of the transcription process, a range of paratexts should be encoded into the basic data of the edition. The ECM of Revelation has the potential to press the boundaries of the standard critical edition to go beyond textual matters, and to dabble in material culture, even though textual issues remain at the forefront of work.

Returning to Rev 13:18, although the text of the notes need not be included in the textual apparatuses, the text of the verse could be configured as a hyperlink that brings the reader to a page where transcribed text of the marginal collations could be accessed, juxtaposed to tagged images of the manuscripts. If a user wishes to use the edition in a way similar to traditional print forms, she is able to continue reading without recourse to the additional information. However, the digital platform offers a way to enhance the functionality of the traditional form by offering ancillary materials that are already captured in XML, the only limitation being that not every exemplar of Revelation was collated for the production of the volume. ${ }^{53}$ The editors of the ECM are not responsible for the breadth of the paratextual and material features of the tradition, but other projects oriented

51 E.g. Houghton and Smith, "Digital Editing," 110-27; Parker, Textual Scholarship, 101-24. Cf. also Tara L. Andrews, "Philology and Critical Edition in the Digital Age," Variants 10 (2013): $61-72$.

52 It is becoming more common to include certain paratextual or codicological features in transcription, e.g. Franz Fischer, "All texts are equal, but...Textual Plurality and the Critical Text in Digital Scholarly Editions," Variants 10 (2013): 77-91 (esp. 86-88).

53 Witnesses were selected based on the data from TuT and thus artefacts that are relatively late and fall into a fairly obvious text family, e.g. 2259, are unlikely to be selected. However, witnesses not initially selected could be input into the digital edition at a later date as necessity (or leisure) dictates. Including full collations of every reading into the apparatus would certainly clutter the already dense apparatus, but it would provide further data for reception historical research as far as variant readings are concerned. 
toward these features could theoretically integrate with the digital ECM fascicles, creating a more deeply curated digital archive, that contains both editorial texts and links to additional information that contextualises particular textual formulations.

All of this could make the edition of the New Testament a more fully integrated interdisciplinary object that appeals to a wider group of users from various fields. A digital edition spurs on the discovery of knowledge and allows us to understand not merely a work's production, but its reception, a point that preponderates in a more comprehensive edition that includes recourse to material culture..$^{54}$ This type of functionality reconnects text to its material witnesses, reversing the necessary divorcing of text from its manuscript in the process of aggregating and evaluation the various textual witnesses of a work. These links and other resources need not be integrated at the outset of its publication, but could be continually edited, updated, and expanded by an editorial team indefinitely (or at least until funding bodies get tired of it). In this sense, the collocation "digital edition" is really a misnomer, since its flexibility transcends the illusion of the fixed nature of print editions. A digital ECM, for example, is more like a repository where primary sources, both texts (transcriptions) and manuscripts (images) are presented on a contingent basis by the primary editors. ${ }^{55}$ A digital edition is supple and adaptable to the critical whims of other users - it is fundamentally open to experimentation. Modern editors stand in a less authoritative position and, although their critical judgments should be taken seriously and evaluated analytically, they also function now as aggregators and curators of data that represent the tradition writ large, including data that is not textual in the traditional sense. Editors are becoming the heads of "digital scriptoria," to borrow a concept from Parker. ${ }^{56}$ The active engagement of users also democratizes editing, allowing users interested in an idiosyncratic exegetical problem like the one I have described for Rev 13:18 to put the book's textual history and material culture

54 Cf. Jerome McGann, “Coda: Why Digital Textual Scholarship Matters,” in The Cambridge Companion to Textual Scholarship, ed. N. Fraistat and J. Flanders (Cambridge: Cambridge University Press, 2013): 274-88.

55 So also Parker, Textual Scholarship, 139-42.

56 Parker, Manuscripts, Texts, Theology: Collected Papers 1977-2007, ANTF 40 (Berlin: de Gruyter, 2009), 287-303 (repr. JSNT 25 [2003]: 395-411). Cf. also Paul Dilley, "Digital Philology between Alexandria and Babel," in Ancient Worlds in Digital Culture, ed. C. Clivaz et al. (Leiden: Brill, 2016): 17-34. 
to good use, although the task of critical editing will likely remain in the hands of a restricted group of experts. ${ }^{57}$

Although the details of the platform remain contingent and fungible, ${ }^{58}$ the possibilities of such a multi-modal digital object have the ability to reinvigorate editorial activity on the New Testament. Such an interactive platform combines the concerns of both "old" and "new" philology. The exemplars discussed above are of little interested when it comes to constructing an Ausgangstext; as members of well-defined textual families, or mixed texts thereof, with mostly derivative texts, they are less than useful for classic textual criticism. But connecting the shared features of the textually uninteresting witnesses injects life into the breadth of the textual tradition in a way that does not detract from textual adjudications.

A digital edition enables thinking about the New Testament that transcends the implicit strictures of print culture, allowing a digital text to engross users in the manuscript tradition and its features that are lost in standard print editions. It also emphasises the contingent nature of critical texts since the ideal digital platform should resemble a work space where the raw data can be reconfigured. ${ }^{59}$ Digital media bypasses print culture to more fully encounter a tradition indebted in deep ways to the venerable practice of manuscript production. "We need a way of bringing the critical edition and the manuscripts as manuscripts back together again." 60 If a critical edition is truly "a tool for understanding the work" 61 or a narrative of the tradition of which the work is a part, then the inclusion of data from material culture, connecting document to text, is surely a desirable benefit of the digital turn. New mediums make new forms of scholarship and interest in the material possible and help us to learn from the peripheries of the tradition, margins like those found in the margins of medieval manuscripts.

57 Cf. Houghton and Smith, "Digital Editing," 124-125; Fischer, "All texts are equal,” 77-91.

58 Cf. David Hamidović, "Editing a Cluster of Texts: The Digital Solution," in Ancient Worlds in Digital Culture, ed. C. Clivaz et al. (Leiden: Brill, 2016): 196-213.

59 Cf. Paul Eggert, “Apparatus, Text, Interface: How to Read a Printed Critical Edition,” in The Cambridge Companion to Textual Scholarship, ed. N. Fraistat and J. Flanders (Cambridge: Cambridge University Press, 2013): 105-06.

60 Parker, Textual Scholarship, 126.

61 Parker, Textual Scholarship, 105. 


\section{Appendix: Manuscripts with Marginal Comments at Revelation 13:18}

\begin{tabular}{llrl}
\hline \multicolumn{2}{c}{ Irenaeus Stream } & & \\
\hline GA Signature & Library Signature & Hoskier Number $^{62}$ & Date \\
\hline 1859 & Athos, Kutlumusiu, 82 & 219 & XIV \\
\hline 2027 & Paris, BnF, gr. 491 & 61 & XIII \\
\hline
\end{tabular}

\begin{tabular}{|c|c|c|c|c|}
\hline \multicolumn{5}{|c|}{ Commentary Streams } \\
\hline $\begin{array}{l}\text { GA } \\
\text { Signature }\end{array}$ & Library Signature & $\begin{array}{l}\text { Hoskier } \\
\text { Number }\end{array}$ & Date & Sub-stream \\
\hline 35 & Paris, BNF, gr. 47 & 17 & $\mathrm{XI}$ & $\begin{array}{l}\text { Andrew } \\
\text { Commentary }\end{array}$ \\
\hline 325 & Oxford, Bodl. Libr., Auct. E. 5.9 & 9 & $\mathrm{XI}$ & \\
\hline 632 & Rome, Bibl. Vallicell. B.86 & 22 & XII/XIV & \\
\hline 757 & Athens, Nat. Bibl. 150 & 150 & XIII & \\
\hline 824 & $\begin{array}{l}\text { Grottaferrata, Bibl. Della Badia, } \\
\text { A. } \alpha .1\end{array}$ & 110 & XIV & \\
\hline 1072 & Athos, Lavra, Г 80 & 160 & XIII & \\
\hline 1075 & Athos, Lavra, $\Lambda 195$ & 161 & XIV & \\
\hline 1248 & Sinai, St. Catherine’s, gr. 267 & 250 & XIV & \\
\hline 1503 & Athos, Lavra, A 99 & 192 & 1317 & \\
\hline 1551 & Athos, Vatopediu, 913 & 212 & XIII & \\
\hline 1597 & Athos, Vatopediu, 966 & 207 & 1289 & \\
\hline 1637 & Athos, Lavra, $\Omega 141$ & 230 & 1328 & \\
\hline 1732 & Athos, Lavra, A 91 & 220 & 1384 & \\
\hline 1740 & Athos, Lavra, B 80 & 229 & XII & \\
\hline 1745 & Athos, Lavra, $\Omega 49$ & 227 & $\mathrm{XV}$ & \\
\hline 1771 & Athos, Lavra, E 177 & 224 & XIV & \\
\hline 1864 & Athos, Stravronikita, 52 & 242 & XIII & \\
\hline 2041 & London, Brit. Libr., Add. 39612 & 96 & XIV & \\
\hline
\end{tabular}

62 See H. C. Hoskier, Concerning the Text of the Apocalypse, vol. 1 (London: Bernard Quaritch, 1929). 
(continued)

\begin{tabular}{|c|c|c|c|c|}
\hline \multicolumn{5}{|c|}{ Commentary Streams } \\
\hline $\begin{array}{l}\text { GA } \\
\text { Signature }\end{array}$ & Library Signature & $\begin{array}{l}\text { Hoskier } \\
\text { Number }\end{array}$ & Date & Sub-stream \\
\hline 2059 & Vatican, Bibl. Vat., Vat. Gr. 370 & 152 & $\mathrm{XI}$ & \\
\hline 2073 & Athos, Iviron, 273 & 169 & XIV & 2073 \\
\hline 2114 & Athens, Nat. Bibl., 142 & 234 & 1676 & \\
\hline 2254 & Athos, Iviron, 382 & 216 & $\mathrm{XVI}$ & \\
\hline 2259 & Athos, Stravronikita, 25 & $(213)$ & $\mathrm{XI}$ & \\
\hline 2323 & Athens, Mus. Benaki, Ms. 46 & & XIII & \\
\hline 2352 & Meteora, Metamorphosis, 237 & 202 & $\mathrm{xV}$ & \\
\hline 2431 & Athos, Kavsokalyvia, 4 & & 1332 & \\
\hline 2554 & $\begin{array}{l}\text { Bucharest, Romanian Academy, } \\
3 / 12610\end{array}$ & & 1434 & \\
\hline 452 & Vatican, Bibl. Vat., Reg. gr. Pii II 50 & 42 & XII & Proper Names \\
\hline 468 & Paris, BNF gr. 101 & 55 & XIII & \\
\hline 699 & London, Brit. Libr., Egerton 3145 & 89 & $\mathrm{XI}$ & \\
\hline 1685 & Athens, Byz. Mus., 155 & $(198)$ & 1292 & \\
\hline 1768 & Athos, Iviron, 771 & & 1519 & \\
\hline 1854 & Athos, Iviron, 231 & 130 & $\mathrm{XI}$ & \\
\hline 1865 & Athos, Philotheu, 1801 & 244 & XIII & \\
\hline 2024 & Moscow, Hist. Mus., V.391 & 50 & $\mathrm{XV}$ & \\
\hline 2079 & Athos, Konstamonitu, 107 & 177 & XIII & \\
\hline 2201 & Elasson, Olympiotissis, 6 & $(252)$ & $\mathrm{xV}$ & \\
\hline 2723 & Trikala, Vissarionos, 4 & & $\mathrm{XI}$ & \\
\hline 2821 & Cambridge, Univ. Libr. Dd. 9.69 & 10 & XIV & \\
\hline
\end{tabular}

\begin{tabular}{llrl}
\hline \multicolumn{2}{c}{ Anti-Islam Stream } & & \\
\hline GA Signature & Library Signature & Hoskier Number & Date \\
\hline 1775 & Athos, Panteleimonos, 110 & 236 & 1847 \\
\hline 1778 & Thessaloniki, Vladaton, 35 & 203 & XV \\
\hline 2072 & Athos, Dochiariu, 81 & $(168)$ & 1789 \\
\hline 2075 & Athos, Iviron, 370 & 171 & XIV \\
\hline 2077 & Athos, Iviron, 644 & 174 & 1685 \\
\hline 2814 & Augsburg, Univ. Libr., Cod. I.1.4.1 & 1 & XII \\
\hline
\end{tabular}




\begin{tabular}{llll}
\hline \multicolumn{3}{c}{ Isolated Note } \\
\hline GA Signature & Library Signature & Hoskier Number & Date \\
\hline 051 & Athos, Pantokratoros, 44 & E & $X$ \\
\hline
\end{tabular}

\begin{tabular}{llrl}
\hline \multicolumn{4}{c}{ Other Possible Manuscripts (Damaged/Illegible) and Minor Notations } \\
\hline GA Signature & Library Signature & Hoskier Number & Date \\
\hline 522 & Oxford, Bodl. Libr., Canon gr. 34 & 98 & $1515 / 1516$ \\
\hline 919 & Escorial, Bibl. De Escorial, $\Psi$ III 6 6 & 125 & XI \\
\hline 1617 & Athos, Lavra, E 157 & 223 & XV \\
\hline 1746 & Athos, Lavra, $\Omega$ 144 & 228 & XIV \\
\hline 2031 & Vatican, Bibl. Vat., Vat. Gr. 1743 & 67 & 1301 \\
\hline 2669 & Athos, Lavra, $\Lambda^{\prime} 74$ & & XVI \\
\hline
\end{tabular}

\section{Bibliography}

Achelis, Hans. Hippolyt's kleinere exegetische und homiletische Schriften. Leipzig: Hinrichs'sche, 1897.

Aland, B., et al., eds. Novum Testamentum Graecum Editio Critica Maior IV. Die Katholischen Briefe, 2nd ed. Stuttgart: DBG, 2011.

Andrews, Tara L. "Philology and Critical Edition in the Digital Age." Variants 10 (2013): 61-72.

Angold, Michael. "Byzantium and the west 1204-1453." In The Cambridge History of Christianity: Eastern Christianity, vol. 5, edited by M. Angold, 53-78. Cambridge: Cambridge University Press, 2008.

Argyriou, Asterios. Les exégèses grecques de l'Apocalypse à l'époque turque (1453-1821): Esquisse d'une histoire des courants ideologiques au sein du people grec asservi. Thessaloniki: Kronoz, 1982.

Aune, D.E. Revelation. WBC 52b. 3 vols. Nashville: Thomas Nelson, 1998.

Bauckham, Richard. The Climax of Prophecy: Studies on the Book of Revelation. Edinburgh: T\&T Clark, 1993.

Beale, G.K. The Book of Revelation. NIGTC. Grand Rapids: Eerdmans, 1999.

Birdsall, J. Neville. "Irenaeus and the Number of the Beast: Revelation 13,18." In New Testament Textual Criticism and Exegesis: Festschrift J. Delobel, edited by A. Denaux, 349-59. Leuven: Peeters, 2002.

Breed, Brennan W. Nomadic Text: A Theory of Biblical Reception History. Bloomington: Indiana University Press, 2014.

Cerquiglini, Bernard. In Praise of the Variant: A Critical History of Philology, trans. B. Wing. Baltimore: The Johns Hopkins University Press, 1999.

Cole, Zachary J. Numerals in Early Greek New Testament Manuscripts: Text-Critical, Scribal, and Theological Studies. NTTSD 53. Leiden: Brill, 2017. 
Constantinou, Eugenia Scarvelis. Guiding to a Blessed End: Andrew of Caesarea and his Apocalypse Commentary in the Ancient Church. Washington, D.C.: The Catholic University of America Press, 2013.

de Groote, Marc ed. Oecumenii Commentarius in Apocalypsin. TEG 8. Leuven: Peters, 1999. de Villiers, Pieter G.R. “Numerical Symbolism in Oecumenius's Commentary on Revelation.”

In Tot sacramenta quot verba: Zu Kommentierung der Apokalypse des Johannes von den Anfängen bis ins 12. Jahrhundert, edited by K. Huber, R. Klotz, and C. Winterer, 135-52. Münster: Aschendorf, 2014.

Dilley, Paul. “Digital Philology between Alexandria and Babel.” In Ancient Worlds in Digital Culture, edited by C. Clivaz, et al., 17-34. Leiden: Brill, 2016.

Dochhorn, Jan. Schriftgelehrte Prophetie: Der eschatologische Teufelsfall in Apc Joh 12 und seine Beudeutung für das Verständnis der Johannesoffenbarung. WUNT 268. Tübingen: Mohr Siebeck, 2010.

Eggert, Paul. “Apparatus, Text, Interface: How to Read a Printed Critical Edition.” In The Cambridge Companion to Textual Scholarship, edited by N. Fraistat and J. Flanders, 97-118. Cambridge: Cambridge University Press, 2013.

Epp, E.J. "The Multivalence of the Term 'Original' Text in New Testament Textual Criticism." HTR 92 (1999): 245-81.

Fischer, Franz. "All texts are equal, but...Textual Plurality and the Critical Text in Digital Scholarly Editions." Variants 10 (2013): 77-91.

Fraistat, Neil, and Julia Flanders. "Introduction to Textual Scholarship in the Age of Media Consciousness." In The Cambridge Companion to Textual Scholarship, edited by N. Fraistat and J. Flanders, 1-15. Cambridge: Cambridge University Press, 2013.

Greetham, David. "A History of Textual Scholarship." In The Cambridge Companion to Textual Scholarship, edited by N. Fraistat and J. Flanders, 17-41. Cambridge: Cambridge University Press, 2013.

Hamidović, David. “Editing a Cluster of Texts: The Digital Solution.” In Ancient Worlds in Digital Culture, edited by C. Clivaz, et al., 196-213. Leiden: Brill, 2016.

Hayles, N. Katherine. Writing Machines. London: MIT Press, 2002.

Hendel, Ronald. Steps to a New Edition of the Hebrew Bible. Atlanta: Society of Biblical Literature, 2016.

Henten, Jan Willem van. “Dragon Myth and Imperial Ideology in Revelation 12-13.” In The Reality of Apocalypse: Rhetoric and Politics in the Book of Revelation, edited by D.L. Barr, 181-203. Atlanta: Society of Biblical Literature, 2006.

Hernández, Juan Jr. "Andrew of Caesarea and His Reading of Revelation: Cathechesis and Paranesis.” In Die Johannesapokalypse: Kontexte - Konzepte - Rezeption, WUNT 287, ed. J. Frey, J.A. Kelhoffer, and F. Tóth, 755-74. Tübingen: Mohr Siebeck, 2012.

Hoskier, H.C. Concerning the Text of the Apocalypse. 2 vols. London: Quaritch, 1929.

Houghton, H.A.G., and Catherine J. Smith. "Digital Editing and the Greek New Testament." In Ancient Worlds in Digital Culture, edited by C. Clivaz et al., 110-27. Leiden: Brill, 2016. Koester, Craig. Revelation. AYB 38a. London: Yale University Press, 2014.

Kolbaba, Tia M. The Byzantine Lists: Errors of the Latins. Chicago: University of Illinois Press, 2000. Kretschmar, Georg. Die Offenbarung des Johannes: Die Geschichte ihrer Auslegung im 1. Jahrtausend. Stuttgart: Calwer, 1985.

Lake, Kirsopp. The Early Days of Monasticism on Mount Athos. Oxford: Clarendon, 1909. Lambros, Spyr. P. Catalogue of the Greek Manuscripts on Mount Athos. Cambridge: Cambridge University Press, 1895. 
Lembke, M., et al., eds. Text und Textwert der griechischen Handschriften des Neuen Testaments. VI. Die Apokalypse. ANTF 49. Berlin: de Gruyter, 2017.

Lembke, Markus. "Beobachtungen zu den Handschriften der Apokalypse des Johannes." In Die Johannesoffenbarung: Ihr Text und ihre Auslegung, edited by M. Labahn and M. Karrer, 19-69. Leipzig: Evangelische Verlagsanstalt, 2012.

McGann, Jerome. Radiant Textuality: Literature after the World Wide Web. New York: Palgrave Macmillan, 2001.

McGann, Jerome. “Coda: Why Digital Textual Scholarship Matters," in The Cambridge Companion to Textual Scholarship, edited by N. Fraistat and J. Flanders, 274-88. Cambridge: Cambridge University Press, 2013.

McGann, Jerome. A New Republic of Letters: Memory and Scholarship in the Age of Digital Reproduction. London: Harvard University Press, 2014.

Mink, Gerd. "Contamination, Coherence, and Coincidence in Textual Transmission." In The Textual History of the Greek New Testament: Changing Views in Contemporary Research, edited by K. Wachtel and M.W. Holmes, 141-216. Atlanta: Society of Biblical Literature, 2011.

Parker, D.C. “A New Oxyrhyncus Papyri of Revelation: P115 (P. Oxy. 4499).” NTS 46 (2000): 159-74.

Parker, D.C. Manuscripts, Texts, Theology: Collected Papers 1977-2007. ANTF 40. Berlin: de Gruyter, 2009.

Parker, D.C. Textual Scholarship and the Making of the New Testament. Oxford: Oxford University Press, 2012.

Schmid, J. Studien zur Geschichte des griechischen Apokalypse-Textes. Munich: Karl Zink, 1955.

Schmid, U. "Die neue Edition der Johannesapokalypse. Ein Arbeitsbericht." In Studien zum Text der Apokalypse, ANTF 47, edited by M. Sigismund, M. Karrer, and U. Schmid, 3-15. Berlin: de Gruyter, 2015.

Sigismund, M. "Die neue Edition der Johannesapokalypse: Stand der Arbeiten." In Studien zum Text der Apokalypse II, ANTF 50, edited by M. Sigismund and D. Müller, 3-17. Berlin: de Gruyter, 2017.

Strutwolf, H., et al., eds. Novum Testamentum Graecum Editio Critica Maior III. Die Apostelgeschichte. Stuttgart: DBG, 2017.

Strutwolf, Holger. "Original Text and Textual History." In The Textual History of the Greek New Testament: Changing Views in Contemporary Research, edited by K. Wachtel and M.W. Holmes, 23-41. Atlanta: Society of Biblical Literature, 2011.

Sutherland, Kathryn. "Anglo-American Editorial Theory." In The Cambridge Companion to Textual Scholarship, edited N. Fraistat and J. Flanders, 42-60. Cambridge: Cambridge University Press, 2013.

Wasserman, Tommy and Peter J. Gurry. A New Approach to Textual Criticism: An Introduction to the Coherence-Based Genealogical Method. Atlanta: Society of Biblical Literature, 2017.

Williams, Peter J. "P115 and the Number of the Beast." TynBul 58 (2007): 151-53.

Zachariadou, Elizabeth A. "Mount Athos and the Ottomans c.1350-1550" In The Cambridge History of Christianity: Eastern Christianity, vol. 5, edited by M. Angold, 154-68. Cambridge: Cambridge University Press, 2008.

Zachariadou, Elizabeth A. "The Great Church in captivity 1453-1586." In The Cambridge History of Christianity: Eastern Christianity, vol. 5, edited by M. Angold, 169-86. Cambridge: Cambridge University Press, 2008. 
